allantois could just be traced into the chorionic end of the cord. Some injection was passed into the vessels of the cord, which filled the principal vessels of the chorion; but as the specimen had been for some time in spirit before the injection was made, it did not enter the vessels of the villi. Slender vessels, however, traversed the non-villous spot opposite the os uteri, and some also were seen subjacent to the amnion where it was in contact with the wall of the tubular prolongation of the allantois situated in the left horn of the chorion.

\title{
EXPLANATION OF PLATE XLIV.
}

Fig. 1. Fœtal membranes of Hyomoschus aquaticus, opened into and fœtus removed; reduced from natural size. $C h$. Villous chorion of the foetal horn. Ch' Villous chorion of the opposite horn. Al. Sac of allantois in the non-fecundated cornu, the communication of which with the tubular prolongation in the fœetal horn is seen to the right of the letters. Am. Sac of the amnion; the letters are placed on the amnion where it is in contact with the chorion. $U$. The umbilical cord ; the letter is placed on the amnion where it is in contact with the allantois. $o$. The non-villous surface of the chorion opposite the os uteri. S.S. The smooth non-villous parts of the chorion in relation to the Fallopian tubes.

2. Magnified view of the free surface of the uterine mucous membrane of Hyomoschus, showing the crypts in which the villi of the chorion are lodged. At $a$ the mouth of one of the uterine glands is shown.

The drawings have been kindly made for us by Mr. J. D. Dunlop.

6. Descriptions of new Asiatic Hesperidæ. By F. Moore, Assistant Curator, India Museum, London.

[Received June 11, 1878.]

\section{(Plate XLV.)}

\section{ISMENE SUBFASCIATA, n. sp.}

Male. Upperside dark velvety umber-brown; costal edge of fore wing slightly ochreous; cilia of both wings ochreons. Underside paler : fore wing with a pale pink triangular costal patch before the apex ; posterior border ochreous, adorned with a large hairy tuft : hind wing with a transverse pink fascia across middle of the wing. Eyes red. Legs beneath and anal tuft ochreous.

Expanse 2 inches.

Hab. Ceylon (In coll. Sir W. H. Gregory and Dr. Thwaites).

Allied to $I$. aria, Moore, from which it may be distinguished by the markings on the underside.

\section{Calliana, n. g.}

Wings ample, broad. Fore wing trigonal ; cell long, broad ; costal vein exteriding to one third from apex; subcostal vein curved at end of the cell, first, second, third, and fourth branches arising at equal distances before end of cell, fifth from its end, the three former ter- 

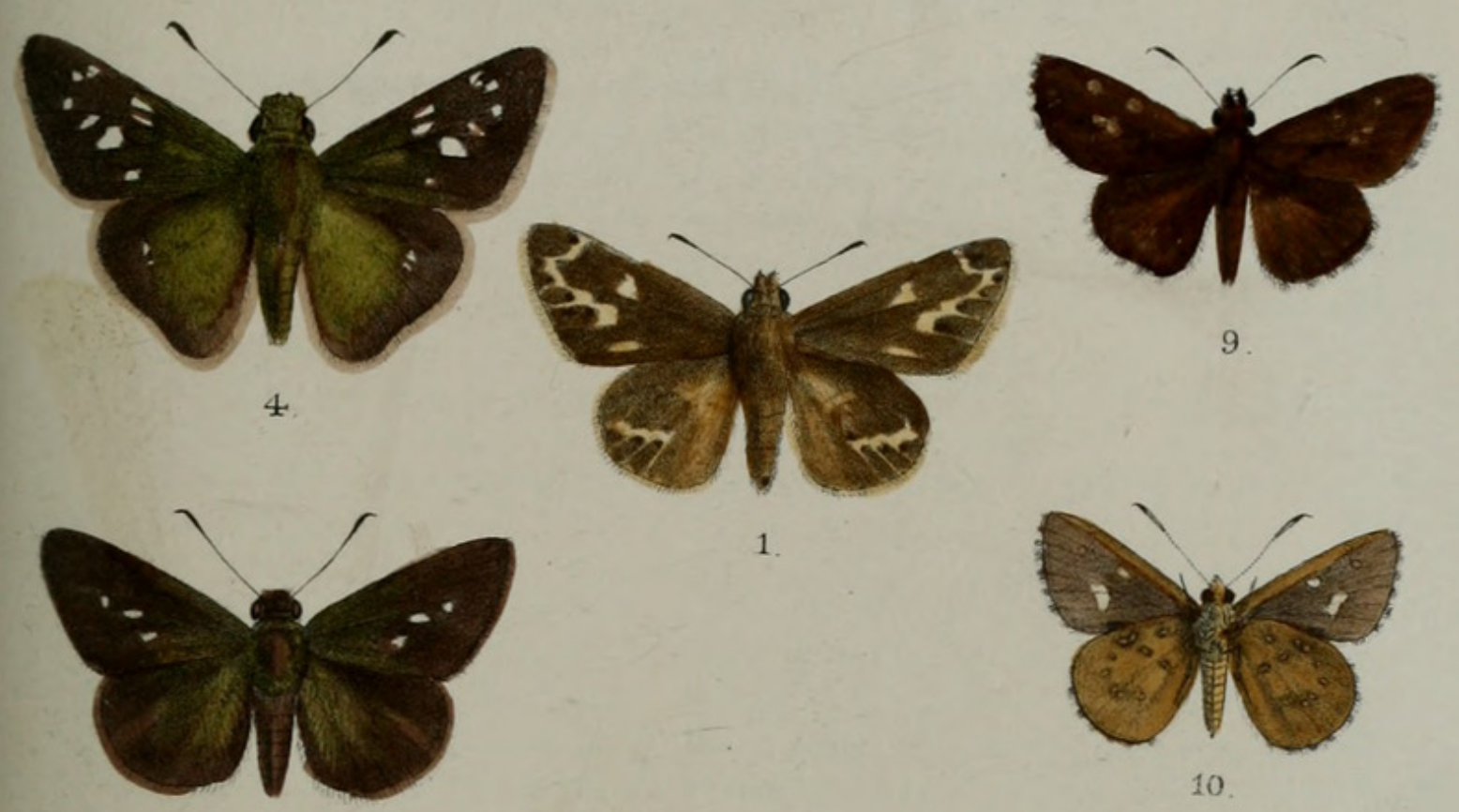

10
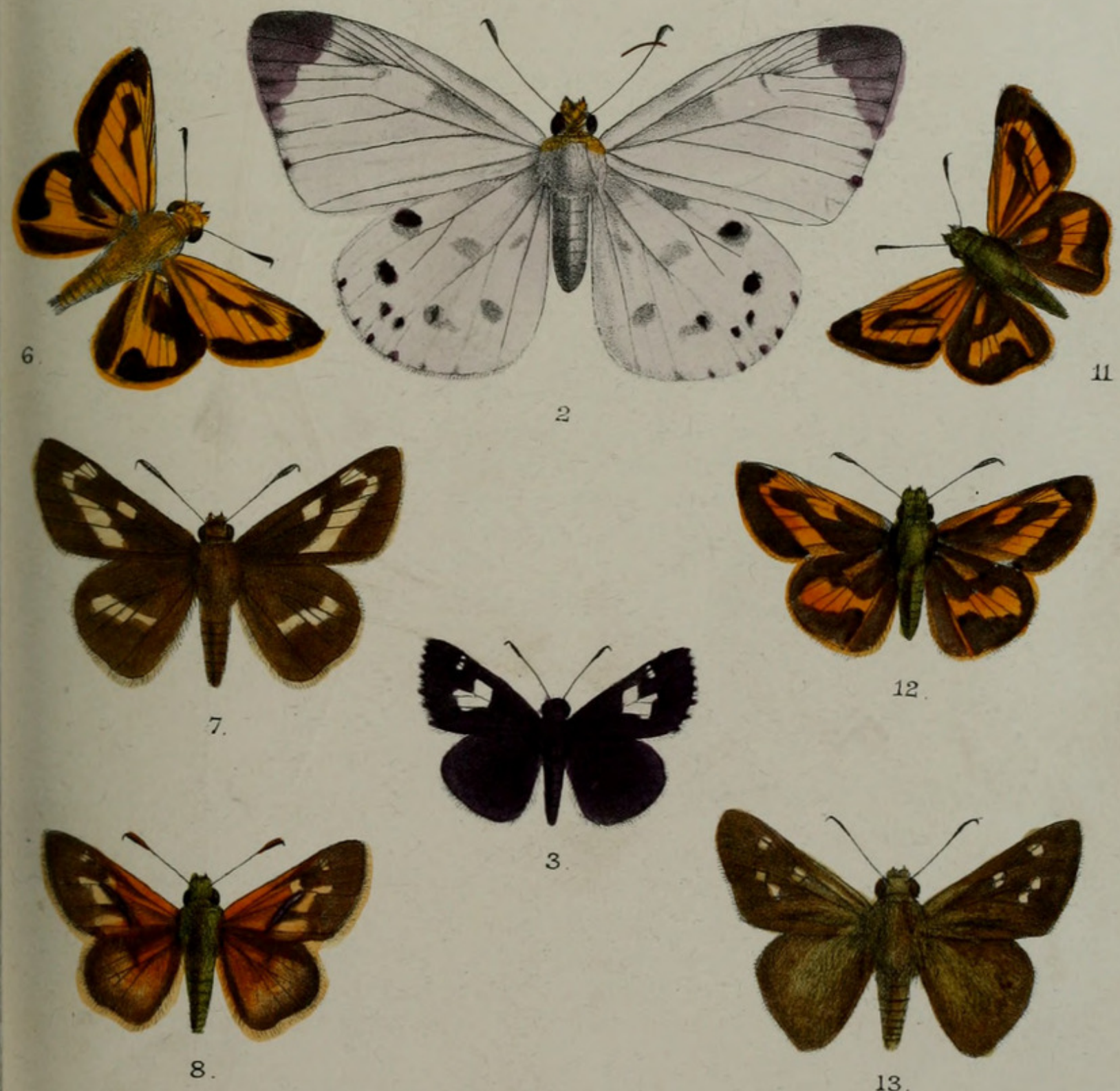

8. 

minating before the apex, fourth at the apex, and fifth below it ; discocellulars angled close to the upper end; upper radial from the angle, lower from their middle ; median vein three-branched, widely apart, the upper from lower end of cell, middle and lower branches at equal distances, the lower from near base of cell ; submedian slightly recurved. Hind wing broadly ovate; subcostal two-branched, second before end of cell; discocellulars slightly angled; radial from their angle; median three-branched, middle branch from immediately before end of cell. Body small, robust, abdomen short. Palpi short, thick, pilose, ascending, third joint short, conical. Antennæ slender. Legs pilose.

\section{Calliana pieridoides, n. sp. (Plate XLV. fig. 2.)}

Male. Upperside creamy-white, glossy ; fore wing with the apex broadly vinous-brown, the end of the median veins also with a vinous-brown-speckled spot: hind wing with a curred upper discal decreasing series of five purple-black spots, the upper one large and situated between the costal and subcostal veins; the end of the veins also with a small vinous-brown-speckled spot. Underside white; fore wing with the costal base, a patch beyond end of the cell, and the outer border pale vinous-brown : hind wing with a short black narrow streak at end of costal border, four large subbasal and a curved discal series of seven purple-black spots, a marginal series of broad vinous-brown spots, one at end of each vein. Thorax and abdomen white; collar, top of head, palpi, and tip of abdomen pale ferruginous; tip of palpi and antennæ black; legs pale ferruginous above, purple-brown beneath.

Expanse $2 \frac{5}{8}$ inches.

Hab. ? N.E. Bengal (A. Grote). In coll. F. Moore.

Hesperia narooa, n. sp. (Plate XLV. fig. 4.)

Male and Female. Upperside dark olive-brown: fore wing with two prominent semidiaphanous yellowish well-separated spots at end of the cell, a subapical series of three smaller spots, and an oblique discal series of five spots: hind wing with two very small discal spots in male, three in female. Underside dark olive-brown; fore wing marked as above : hind wing with a prominent white spot at upper end of the cell, and a curved discal series of four spots. Body olive-green.

Expanse $1 \frac{9}{12}$ inch.

Hab. Bombay (Wilkinson); Ceylon (Mackwood). In coll. F. Moore and F. M. Mackwood.

Allied to $H$. contigua, Mabille ; markings similar, but both sexes one third less in size.

\section{Hesperia Kumara.}

Hesperia kumara, Moore, Catal. Lep. E.I. C. i. p. 255 (1857).

Female. Upperside dark olive-brown; fore wing with a transverse discal series of seven yellowish semidiaphanous spots from before the apex ; cilia pale brownish-yellow. Underside deep ochreous-brown : 
fore wing marked as above, the lowest spot being yellow : hind wing with a single discal indistinct yellow spot between the two lower median branches. Palpi and body brown; tarsi ochreous.

Expanse 1 $\frac{5}{8}$ inch.

Hab. Canara (S. N. Ward). In coll. India Museum, London.

This species is also found in Ceylon, the male differing from the female above and beneath in the first upper and lowest discal spots being obsolete.

\section{Hesperia seriata, n. sp.}

Allied to H. kumara. Male differs from the same sex of that species in the discal row of spots being slightly smaller, and in having an additional lower small spot (which is present only in the female of $H$. kumara). Underside greenish brown; fore wing marked as above, the lowest spot suffused.

Expanse $1 \frac{5}{8}$ inch.

Hab. Ceylon. In coll. F. M. Mackwood and F. Moore.

\section{Hesperia bevani, n. sp.}

Male. Upperside dark olive-brown; cilia pale brownish-cinereous; fore wing with a single small, pale white, semidiaphanous spot at upper end of the cell, three contiguous subapical spots, another below these, and two larger spots below obliquely on the disk, a small spot also very indistinctly visible on middle of submedian vein : hind wing without spots. Underside greyish olive-brown; spots slightly more prominent than above : hind wing with a discal series of five small somewhat indistinct white spots.

Expanse 1 $\frac{2}{8}$ inch.

Hab. Salween, Moulmain (Lieut. Bevan). In coll. F. Moure.

A male specimen of this species from Calcutta, collected by the late Mr. Atkinson, is in the collection of Dr. O. Staudinger.

Hesperia bada, n. sp.

Alled to $H$. mangala.

Male and Female. Upperside dark brown, base of wings olivebrown; cilia pale cinereous-brown: fore wing with two (in some specimens three) contiguous subapical small white semidiaphanous spots, and three spots below obliquely on the disk, the upper one the smallest: hind wing with a discal irregular linear series of three or four white semidiaphanous spots, more or less indistinct. Underside greyish-brown; both wings marked as above, the spots on the hind wing being more prominent.

Expanse, of $1 \frac{2}{10}$, ㅇ․ $1 \frac{3}{10}$ inch.

Hab. Ceylon. In coll. F. Moore.

Also in the collection of Dr. O. Staudinger from Malacea.

Hesperia farri, n. sp.

Male and Female. Upperside ferruginous-brown, base of both wings olive-brown; cilia yellowish-cinereous : fore wing with two pale yellow semidiaphanous spots at end of the cell, and a discal recurved 
series of seven spots, the four upper and the seventh smallest, the upper three being contiguous and obliquely before the apex, the sixth below end of the cell and the largest. Underside greyerbrown in the female : fore wing marked as in male, except that the lowest spot is more diffused : hind wing without spots.

Expanse, of $1 \frac{4}{8}$, o $1 \frac{5}{8}$ inch.

Hab. Calcutta (Farr); Cherra Punji (Atkinson). In coll. F. Moore and Dr. Staudinger.

\section{Hesperia toona, n. sp.}

Allied to H. eltola, Hewits. Exot. Butt. Hesp. pl. 4. f. 40.

Male. Differs in the fore wings being slightly more elongate, the hind wing more convex exteriorly, and the anal angle less lobed; markings above similar, those on the fore wing narrower, the spot between the median branches elongated and extending to their basal angle ; those on the hind wing very small, the outer spot crossed by a vein. Underside brownish-ochreous; base of fore wing slightly dusky-ochreous ; markings as above.

Expanse $1 \frac{5}{12}$ inch.

Hab. N.E. Bengal (A. Grote). In coll. F. Moore.

Hesperia subgrisea, n. sp. (Plate XLV. fig. 5.)

Allied to $H$. gremius, Fabr. (Butler, Catal. Fabr. Lep. B. M. p. 271, pl. 3. f. 7).

Male. Differs above in having the three oblique discal spots smaller, the lowest appearing only as a few greenish-grey scales, the upper subapical series of two and a single spot at upper end of the cell very minute. Underside less grey in colour, the fore wing marked as above; hind wing with an indistinct black cell-spot and a discal series of spots.

Expanse 1 $\frac{4}{8}$ inch.

Hab. Ceylon. In coll. F. M. Mackwood and F. Moore.

\section{Pithauria, n. g.}

Fore wing elongated, narrow ; apex pointed ; exterior margin very oblique; hind margin short; hind wing convex externally, lobular at anal angle. Head and thorax very broad, robust; abdomen not so long as hind wing. Antennæ with a slender club and very long whip-like tip. Venation similar to Pamphila.

Pithauria murdaya. (Plate XLV. fig. 13.)

Hesperia murdava, Moore, P. Z. S. 1865, p. 784 .

Hab. Darjiling.

\section{HaLPe, n. g.}

Allied to Pamphila (P. sylvanus). Antennæ with a more slender club and longer hook at tip. Fore wing shorter; exterior margin more convex; the discal oblique series of raised scales in male shorter and broader. Head and thorax smaller; abdomen slender. Veins similar, the lower median branch being nearer end of the cell. 
Halpe Ceylonica, n. sp. (Plate XLV. fig. 9.)

Upperside dark brown; base of wings and body olive-brown; fore wing with two contiguous subapical small white spots, two oblique discal small conical spots with deeply excavated outer border, and a smaller spot at upper end of the cell; the male with an oblique discal streak composed of broad raised darker brown scales; cilia brownish-cinereous, alternated with dark brown. Underside dark brown, speckled with ochreous scales; fore wing with white spots as above, and a small spot also below the discal series; an upper submarginal row of indistinct pale ochreous spots; hind wing with a broad transverse median and a maculated discal greyishochreous band. Palpi, body beneath, and legs greyish-ochreous.

Expanse, of $1 \frac{2}{10}$, 우 $1 \frac{2}{8}$ inch.

Hab. Ceylon. In coll. F. M. Mackwood and F. Moore.

\section{Halpe beturia.}

Hesperia beturia, Hewitson, Descr. Hesp. p. 36 (1868).

Hab. Calcutta district (Atkinson and Farr); Andamans (Roepstorff).

\section{Halpe luteisquama.}

Pamphila luteisquama, Mabille.

Hab. Luzon.

\section{Halpe dolopia.}

Hesperia dolopia, Hewitson, Deser. Hesp. p. 27 (1868); Exot. Butt. Hesp. pl. 6. f. 60, 61 .

Hab. Darjiling (Atkinson).

Halpe radians, n. sp. (Plate XLV. fig. 1.)

Male. Upperside luteous-brown, basal hairy scales yellow. Cilia cinereous-white : fore wing with a pale yellow constricted spot at end of the cell, and an irregular transverse centinuous discal band of spots with their lower angles continued outward along the veins; hind wing with a yellow streak at end of the cell, and a short discal band with outer rays. Underside paler, minutely speckled with yellowish-white; fore wing as above, the hind margin being also broadly yellow ; hind wing with a subbasal spot, all the veins, and two (a median and a discal) transverse sinuous bands pale yellow. Palpi, body beneath, and legs yellowish-white.

Expanse $1 \frac{1}{2}$ inch.

Hab. Dhurmsala, N.W. Himalaya. In coll. F. Moore.

Pamphila palmarum, n. sp. (Plate XLV. figs. $6 \& 7$, $q$ o 0 .)

Differs from typical Java specimens of $P$. augias, Linn., in its much larger size, the male having the markings above paler yellow and broader, the impressed oblique discal streak on the fore wing being obsolete, the outer border of the discal band much less sinuous, and the yellow colour not extending along the veins to the exterior margin of the wing. 
Female. Paler brown above, the yellow bands on the upperside also paler, less prominent, and there being no yellow along the costal border of fore wing, and no median streak from base of the hind wing. Underside pale vinous-brown, this colour pervading the upper portion of the discal on the fore wing and the entire discal band on the hind wing.

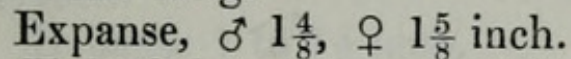

Hab. Calcutta (Grote and Atkinson). In coll. F. Moore and Dr. Staudinger.

"Larva feeds on the date and cocoa-nut palms" (Atkinson, MS. note).

Pamphila bambuse, n. sp. (Plate XLV. figs. $11 \& 12, \sigma^{\circ} q$ ).

Allied to P. augias, Linn., from typical Java specimens of which it differs in its somewhat broader and less pointed wings. Markings above similar, but more defined, the borders of the wings blacker, the basal yellow streak on hind wing confined to a terminal spot at the end of the cell, and the abdominal border black. On the underside the markings are also more clearly defined and the interspaces blacker.

Expanse, of $1 \frac{3}{8}$, ㅇ $1 \frac{4}{8}$ inch.

Hab. Calcutta (Frith and Atkinson). In coll. F. Moore and Dr. Staudinger.

"Larva feeds on the bamboo" (Atkinson, MS. note).

Pamphila subochracea, n. $\mathrm{sp}$.

Upperside glossy luteous olive-brown; cilia yellowish-cinereous. Male. Fore wing with two pale semidiaphanous spots at end of the cell, three contiguous spots obliquely before the apex, three upper discal spots, below which is a narrow white oblique streak or brand: hind wing with three small yellow upper discal spots, the two lowest small. Female. Fore wing with a lower or fourth discal spot, and a small dot below the third spot; the spots angled outward: hind wing as in male. Underside greenish-ochreous, brown on hind border of fore wing and anal lobe ; marginal line brown and prominent : fore wing with the lower spot diffused and white: hind wing with the upper discal white spot large and quadrate; four spots below in a slightly linear position, the upper spot indistinct; a white spot also at upper end of cell, and a smaller indistinct spot above it.

Expanse, o $1 \frac{3}{8}$, $+91 \frac{5}{8}$ inch.

Hab. Calcutta (Atkinson). In coll. Dr. Staudinger.

Allied to $P$. mathias, Fabr., but of larger size and more prominently marked.

Pamphila brahma, n. sp. (Plate XLV. fig. 8.)

Male. Upperside deep ochreous-brown, basal area ochreous. Cilia cinereous-yellow : fore wing with a black-bordered white streak obliquely below the cell, a semidiaphanous yellowish-white constricted spot at end of cell, a small subapical streak of three spots, and two large discal spots, the one above hind margin being ochreous : hind 
wing with an indistinct cell-spot and a discal series of three pale yellowish, semidiaphanous spots. Underside greenish-ochreous; costal base of fore wing ochreous-red, hind margin broadly dusky black and centred by a white streak; markings as above, but less distinct.

Female brown above, with less ochreous at base, the spots more prominent. Underside as in male.

Expanse $1 \frac{3}{8}$ inch.

Hab. Masuri, 7000 feet, N.W. Himalaya. In coll. Major Lang and F. Moore.

Nearest allied to $P$. subhyalina, Ménétr., from China.

\section{Pamphila siva, n. sp.}

Male. Allied to preceding (P. brahma). Darker brown above, the base of fore wing and large lower discal spot only being ochreous, upper semidiaphanous spots brighter yellow, the one between the lower median branches broader; spots on hind wing prominent. Underside brighter greenish-ochreous, base of costa not ochreous red: spots on hind wing clear white, very prominent and with dark border.

Expanse $1 \frac{3}{8}$ inch.

Hab. Khasia hills (G. Austen). In coll. F. Moore.

\section{Astictopterus olivascens, n. sp.}

Allied to A. unicolor, Brem. (Ménétr. Catal. Mus. Pet. Lep. i. t. 5. f. 6), from Pekin and Hong Kong, but of larger size. Upperside uniform glossy olive-brown. Female with a white, semidiaphanous, narrow subapical spot crossed by the fourth and fifth subcostal branches. Underside : male uniformly brown; hind wing sparsely grey-speckled : female with subapical spot on fore wing as above, the exterior margin grey-speckled; hind wing with three ill-defined, sparsely grey-speckled, transverse bands. Palpi, body, and legs beneath grey.

Expanse $1 \frac{6}{10}$ inch.

Hab. Salween, Moulmain (Lieut. R. C. Bevan); Darjeeling (Atkinson and Dr. Staudinger). In coll. F. Moore.

\section{Cyclopides subvittatus, n. sp.}

Male and Female. Upperside dark vinous-brown; extreme edge of both the costa and cilia chrome-yellow. Female with an oblique subapical small chrome-yellow streak, composed of three connected spots crossed by two branches of subcostal vein. Underside: fore wing vinous-brown, with the costal vein, subcostal veins along their marginal end, and a narrow outer marginal band chrome-yellow : hind wing chrome-yellow, with partly interrupted black streaks between the veins.

Expanse $\frac{11}{12}$ inch.

Hab. Salween district, Moulmain (Lieut. R. C. Bevan), In coll. F. Moore.

Note. Also in Mr. Atkinson's collection, labelled Darjiling. 
Cyclopides subradiatus, n. sp.

Male and Female. Allied to C. subvittatus. Differs in being larger, the fore wing ahove having a very indistinct yellow streak, which is composed of two well-separated spots only. Underside brighter-coloured, and the streak between the veins more clearly defined.

Expanse-1 to $1 \frac{1}{8}$ inch.

Hab. Khasia hills (Godwin-Austen). In coll. F. Moore.

Isoteinon atk insoni, n. sp. (Plate XLV. fig. 10.)

Male. Upperside dark glossy olive-brown; cilia brownish cinereous, with a brown inner line and indistinct bars : fore wing with a small yellow semidiaphanous spot at end of the cell, three smaller contiguous spots obliquely before the apex, and two contiguous spots obliquely on the disk. Underside speckled with ochreous-green : fore wing marked as above : hind wing with a median discal curved series of eight small prominent white spots, and a spot at end of the cell.

Expanse $1 \frac{1}{10}$ inch.

Hab. Darjiling (Atkinson). In coll. Dr. Staudinger.

\section{ISOTEINON KHASIANUS, n. $\mathrm{sp}$.}

Male. Upperside glossy ochreous-brown ; cilia brownish-cinereous, with a brown inner line and indistinct bars : fore wing with a small silky-white semidiaphanous spot at end of the cell, three contiguous spots before the apex and two on the disk. Underside rufous-brown : fore wing marked as above; a small tuft of black hairs on middle of hind margin : hind wing grey-speckled, a small white spot at end of the cell, and a median discal curved series of white dots, each surrounded by dark brown.

Expanse $1 \frac{1}{10}$ inch.

Hab. Khasia hills (Godwin-Austen). In coll. F. Moore.

A specimen of what I believe to be the female of this species is in the collection of Dr. Staudinger, but without a locality (though probably Indian). It differs from the male above described in having the spots on the fore wing slightly larger, the cell-spot transversely elongated, and in there being an additional spot below the two on the disk. It is also greyer on the underside; the hind margin on the fore wing has a very pale border; and the hind wing has no perceptible white dots.

Isoteinon masuriensis, n. sp. (Plate XLV. fig. 3.)

Male and Female. Upperside bluish purple-brown. Cilia white, alternated with brown : fore wing with a large semidiaphanous white quadrate spot at end of the cell, two contiguous elongated spots below it (and in the male a smaller spot below these), three very small spots before the apex. Underside dark brown, numerously speckled with ochrey-brown scales : fore wing marked as above : hind wing with a discal series of three small indistinct white spots, one being 


\section{$2 \mathrm{BHL}$ Biodiversity Heritage Library}

Moore, F. 1878. "Descriptions of new Asiatic Hesperidae." Proceedings of the Zoological Society of London 1878, 686-695.

View This Item Online: https://www.biodiversitylibrary.org/item/90451

Permalink: https://www.biodiversitylibrary.org/partpdf/67238

\section{Holding Institution}

Natural History Museum Library, London

\section{Sponsored by}

Natural History Museum Library, London

\section{Copyright \& Reuse}

Copyright Status: Public domain. The BHL considers that this work is no longer under copyright protection.

This document was created from content at the Biodiversity Heritage Library, the world's largest open access digital library for biodiversity literature and archives. Visit BHL at https://www.biodiversitylibrary.org. 